\title{
Analisis Kinerja Simpang Tak Bersinyal Persimpangan Pasar Sibuhuan, Kabupaten Padang Lawas, Sumatera Utara
}

\author{
Performance Analysis of Non Signal Intersection at Sibuhuan Market Intersection, Padang \\ Lawas Regency, North Sumatra
}

\author{
Desi Yanti Futri Citra Hasibuan 1,*, Muchammad Zaenal Muttaqin ${ }^{1}$ \\ 1Program Studi Teknik Sipil, Universitas Islam Riau, , Jl. Kaharuddin Nasution No. 113 Pekanbaru, Riau, Indonesia
}

\begin{abstract}
* Penulis korespondensi : desiyantifutricitra@student.uir.ac.id
Tel.: +62-853-5899-6603; fax.:-

Diterima: 01 Februari 2021; Direvisi: 15 Maret 2021; Disetujui: 20 Maret 2021.

DOI: 10.25299/saintis.2021.vol21(01).6507
\end{abstract}

\begin{abstract}
Abstrak
Persimpangan adalah bagian dari ruas jalan dimana arus dari berbagai arah atau jurusan bertemu. Itulah sebabnya di persimpangan terjadi konflik antara arus dari jurusan yang berlawanan dan saling memotong, sehingga mnengakibatkan terjadinya kemacetan di sepanjang lengan simpang. Begitu juga pada simpang empat lengan tak bersinyal di Pasar Sibuhuan, Kabupaten Padang Lawas, Sumatera Utara terjadi kemacetan yang disebabkan oleh berkurangnya lebar efektif jalan karena adanya parkir dibadan jalan. Pada simpang empat lengan tak bersinyal di Pasar Sibuhuan, Kabupaten Padang Lawas, Sumatera Utara terjadi kemacetan yang disebabkan hambatan samping, tingginya populasi kendaraan yang tidak diimbangi dengan ketersediaan infrastruktur (prasarana) yang memadai sehingga penelitian ini bertujuan untuk menganalisis kinerja simpang empat lengan tak bersinyal tersebut berdasarkan Manual Kapasitas Jalan Indonesia (MKJI) 1997 dan menganalisis persimpangan untuk meningkatkan kinerja simpang tak bersinyal tersebut. Analisis hasil penelitian menunjukkan kinerja simpang untuk kondisi simpang tak bersinyal pada kondi eksisting dengan adanya parkir disisi jalan yang mengurangi lebar efektif, didapat jumlah arus total maksimum $2341 \mathrm{smp} / \mathrm{jam}$, kapasitas (C) = 2707,06 smp/jam, dan derajat kejenuhan (DS) $=0,86$, tundaan simpang $(\mathrm{D})=14,62 \mathrm{detik} / \mathrm{smp}$ dan peluang antrian (QP) 30,03 - 59,32\%. Maka dari itu perlu dilakukan perhitungan ulang dengan berbagai alternatif agar nilai DS memenuhi persyaratan Manual Kapasitas Jalan Indonesia yaitu $<0,75$.
\end{abstract}

Kata Kunci: Persimpangan, Derajat Kejenuhan, MKJI 1997, Padang Lawas

\begin{abstract}
An intersection is a part of a road a where currents from different directions of direction meet. That is why at the instersection there is conflict between current from opposite directions and and intersecting each other, resulting in congestion along the arms of the intersection. Likewise, at the intersection of four arms without a signal at Sibuhuan Market, Padang Lawas Regency, North Sumatra, there was a congestion caused by the reduction in the effective width of the road due to parking on the road. At the intersection of four arms without a signal at Sibuhuan Market, Padang Lawas Regency, North Sumatra, there is a congestion caused by side obstacles, a high vehicle population that is not matched by the availability of adequate infrastructure (infrastructure) so that this study aims to analyze the performance of the four-arm intersection. based on the Indonesian Road Capacity Manual (MKJI) 1997 and analyzes intersections to improve the performance of these unmarked intersections. The analysis of the results showed that the intersection performance for the unsigned intersection conditions in the existing condition with the parking on the side of the road which reduced the effective width, the maximum total flow was 2341 pcu / hour, capacity $(C)=2707.06 \mathrm{pcu} /$ hour, and the degree of saturation $(D S)=0.86$, intersection delay $(D)=14.62$ seconds $/$ pcu and queuing opportunity (QP) 30.03 - 59.32\%. Therefore it is necessary to recalculate with various alternatives so that the DS value meets the requirements of the Indonesian Road Capacity Manual, which is $<0.75$.
\end{abstract}

Keywords: Intersection, Degree Of Saturation, MKJI 1997, Padang Lawas

\section{PENDAHULUAN}

Jalan merupakan psarana angkutam darat yang mempunyai peranan penting dalam memperlancar kegiatan hubungan perekonomian dan hubungan kegiatan sosial, serta berperan besar dalam kemajuan dan perkembangan suatu daerah. Lalu ini lintas merupakan hal yang sangat penting dalam meningkatkan mobilitas sosial masyarakat [1]. Setiap waktu masyarakat terus bergulat dengan lalu lintas dengan bermacam-macam kepentingan [2]. Perkembangan volume lalu lintas di Sumatera
Utara terus meningkat akibat dari pertumbuhan dan perkembangan daerah serta laju pertumbuhan penduduk. Pertumbuhan volume lalu lintas yang tidak diiringi dengan pertambahan infrastruktur jalan seringkali mengakibatkan kemacetan. Kemacetan lalu lintas merupakan masalah utama di kota-kota besar yang terutama dirasakan pada jamjam sibuk, pagi, siang maupun sore hari [3].

Sama halnya dengan dengan perkembangan volume lalu lintas di Kabupaten Padang Lawas khususnya di Pasar Sibuhuan yang merpakan wilayah komersial yang memiliki tingka kmeacetan 
yang tinggi. Dimana pada simpang tersebut tedapat sebuah pasar yang merupakan pusat perdagangan tepat di Jl. Sibuhuan-Gunung Tua dan Jl. Prof. H. M Yamin SH dengan hambatan samping yang tinggi [4]. Hal ini disebabkan adanya aktifitas pasar, kendaraan yang parkir pada badan jalan dan kendaraan keluar masuk pada lengan simpang [5].

Dari permsalahan di atas dapat disimpulkan bahwa simpang empat Pasar Sibuhuan perlu dilakukan evaluasi dan analisa baik kinerja pengaturan lalu lintas, pelebaran jalan, kondisi eksisting dari simpang tak bersinyal menjadi simpang bersinyal untuk dapat mengatasi permasalahan yang ada secara optimal [6].

Adapun tujuan dari penelitian ini adalah yaitu untuk mengetahui kinerja lalu lintas eksisting pada persimpangan di Jl. Simpang empat Pasar Sibuhuan, Kabupaten Padang Lawas, Sumatera Utara.

Batasan masalah pada penelitian ini dilakukan di persimpangan simpang tak bersinyal Pasar Sibuhuan, Kabupaten Padang Lawas, Sumatera Utara. Penelitian ini dibagi dalam 3 (tiga) sesi yaitu jam 06.00-08.00 WIB, jam 12.00-14.00 WIB, dan jam 16.00-18.00 WIB selama 2 (dua) hari sibuk (Senin dan Selasa) dan 1 (satu) hari tak sibuk (Sabtu).

\section{METODOLOGI}

Pada dasarnya dalam melakukan penelitian terhadap suatu obyek pentingnya pemahaman pola pikir penelitian yang akan dilakukan. Pola pikir akan membantu mengarahkan penelitian yang akan dilakukan. Penyusunan dalam penelitian ini dititk beratkan pada volume arus lalu lintas yang melewati persimpangan simpang tak bersinyla Pasar Sibuhuan, Kabupaten Padang Lawas, Sumatera Utara, data jumlah penduduk Kabupaten Padang Lawas, dan mengukur lengan simpang serta melihat kondisi persimpangan tersebut.

Penelitian ini menggunakan cara observase lapangan yaitu survey utama dengan cara pencatatan manual per 2 (dua) jam dan dengan pengukuran langsung menggunakan meteran untuk mendapatkan lebar lengan simpang dan lebar parkir, kemudian dilakukan anlisis terhadap data yang diperoleh. Survey dilakukan pada hari kerja yaitu hari Senin dan Selasa lalu pada hari tak kerja yaitu hari Sabtu, dengan pertimbangan bahwa harihari tersebut mewakili jam-jam sibuk dan volume lalu lintas diperkirakan berbeda jauh. Pertimbangan lain yang juga sangat berpengaruh adalah lokasi penelitian yang merupakan kawasan perdagangan yang banyak dikunjungi, tertuma pada hari kerja. Lokasi penelitian merupakan simpang tak bersinyal dengan 4 (empat) lengan tanpa median yang kemudian dilakukan pengamatan sebanyak 3 (tiga) sesi selama 2 (dua) jam yaitu pukul 06.00-08.00 WIB, lanjut ke sesi berikutnya pukul 12.00-14.00 WIB, dan sesi terakhir pukul
16.00-18.00 WIB, pengamatan yang dilakukan dengan interval 5 menit.

Variabel masukan untuk lebar pendekat dan tipe simpang dapat dulihat pada Tabel 1 dan 2, sebagai berikut:

Tabel 1. Jumlah Lajur dan Lebar Rata-rata pendekat Minor dan Utama

\begin{tabular}{|c|c|}
\hline $\begin{array}{c}\text { Lebar rata-rata pendekat } \\
\text { minor dan utama } \mathrm{W}_{\mathrm{AC}} \\
\text { dan } \mathrm{W}_{\mathrm{BD}}\end{array}$ & $\begin{array}{c}\text { Jumlah lajur (total } \\
\text { untuk dua arah) }\end{array}$ \\
\hline $\mathrm{WB}_{\mathrm{BD} \mathrm{B}}=(\mathrm{b}+\mathrm{d} / 2) / 2<5,5$ & 2 \\
$\geq 5,5$ & 4 \\
\hline $\mathrm{WB}_{\mathrm{AC} \text { B }}=(\mathrm{a} / 2+\mathrm{c} / 2) / 2<$ & 2 \\
5,5 & 4 \\
$\geq 5,5$ & \\
\hline
\end{tabular}

Tabel 2. Tipe Simpang

\begin{tabular}{|c|c|c|c|}
\hline $\begin{array}{c}\text { Kode } \\
\text { IT }\end{array}$ & $\begin{array}{c}\text { Jumlah lengan } \\
\text { simpang }\end{array}$ & $\begin{array}{c}\text { Jumlah } \\
\text { lajur jalan } \\
\text { minor }\end{array}$ & $\begin{array}{c}\text { Jumlah } \\
\text { lajur jalan } \\
\text { minor }\end{array}$ \\
\hline 322 & 3 & 2 & 2 \\
\hline 324 & 3 & 2 & 4 \\
\hline 342 & 3 & 4 & 2 \\
\hline 422 & 4 & 2 & 2 \\
\hline 424 & 4 & 2 & 4 \\
\hline
\end{tabular}

Nilai kapasitas dasar $\left(\mathrm{C}_{0}\right)$ dapat diketahui berdasarkan tipe simpang yang terdapat dalam Tabel 3. ebagai berikut:

Tabel 3. Kapasitas Dasar $\left(\mathrm{C}_{0}\right)$

\begin{tabular}{|c|c|}
\hline Tipe Simpang IT & Kapasitas Dasar (smp/jam) \\
\hline 322 & 2700 \\
\hline 342 & 2900 \\
\hline 324 atau 344 & 3200 \\
\hline 422 & 2900 \\
\hline 424 atau 444 & 3400 \\
\hline
\end{tabular}

Cara perhitungan Kapasitas (C) dapat dihitung dengan ketentuan dari MKJI 1997 dengan rumus Kapasitas (C) sebagai berikut:

$\mathrm{C}=\mathrm{C}_{0} \times \mathrm{F}_{\mathrm{W}} \times \mathrm{F}_{\mathrm{M}} \times \mathrm{F}_{\mathrm{CS}} \times \mathrm{F}_{\mathrm{RSU}} \times \mathrm{F}_{\mathrm{LT}} \times \mathrm{F}_{\mathrm{RT}} \times \mathrm{F}_{\mathrm{MI}}$

Keterangan:

$\mathrm{C}=$ Kapasitas (smp/jam)

$\mathrm{C}_{0} \quad=$ Kapasitas dasar ( $\left.\mathrm{smp} / \mathrm{jam}\right)$

$\mathrm{F}_{\mathrm{W}}=$ Faktor penyesuaian lebar pendekat

$\mathrm{F}_{\mathrm{M}}=$ Faktor penyesuaian median jalan utama

$\mathrm{F}_{\mathrm{CS}}=$ Faktor penyesuaian ukuran kota

$\mathrm{F}_{\mathrm{RSU}}=$ Faktor penyesuaian tipe lingkungan jalan, hambatan samping dan kendaraan tak bermotor

$\mathrm{F}_{\mathrm{LT}}=$ Faktor penyesuaian belok kiri

$\mathrm{F}_{\mathrm{RT}}=$ Faktor penyesuaian belok kanan

$\mathrm{F}_{\mathrm{MI}}=$ Faktor penyesuaian arus jalan minor

Faktor penyesuaian lebar pendekat $\left(\mathrm{F}_{\mathrm{W}}\right)$ dihitung berdasarkan tipe simpang, dengan menggunakan persamaan (2), sebagi berikut: $\mathrm{F}_{\mathrm{W}}=0,70+0,0698 \mathrm{~W}_{1}$ 
Keterangan :

$\mathrm{F}_{\mathrm{W}}=$ Faktor penyesuaian lebar pendekat

$\mathrm{W}_{1}=$ Lebar rata-rata pendekat $(\mathrm{m})$

Variabel masukan untuk tipe median jalan utama terdapat padal Tabel 4, untuk faktor penyesuaian ukuran kota terdapat pada Tabel 5 dan untuk faktor penyesuain tipe lingkungan jalan, hambatam samping, dan kendaraan tak bermotor terdapat pada Tabel 6, berikut:

Tabel 4. Faktor Penyesuaian Median Jalan Utama

\begin{tabular}{|c|c|c|}
\hline Uraian & Tipe M & $\begin{array}{c}\text { Faktor Penyesuain } \\
\text { Median Jalan Utama } \\
\left(\mathrm{FM}_{\mathrm{M}}\right)\end{array}$ \\
\hline $\begin{array}{c}\text { Tidak median jalan } \\
\text { utama }\end{array}$ & $\begin{array}{c}\text { Tidak } \\
\text { ada }\end{array}$ & 1,00 \\
\hline $\begin{array}{c}\text { Ada median jalan } \\
\text { utama, lebar }<3 \mathrm{~m}\end{array}$ & Ada & 1,05 \\
\hline $\begin{array}{c}\text { Ada median jalan } \\
\text { utama, lebar } \geq 3 \mathrm{~m}\end{array}$ & Ada & 1,20 \\
\hline
\end{tabular}

Tabel 5. Faktor Penyesuaian Ukuran Kota

\begin{tabular}{|c|c|c|}
\hline $\begin{array}{c}\text { Ukuran Kota } \\
(\mathrm{CS})\end{array}$ & $\begin{array}{c}\text { Penduduk } \\
\text { (juta) }\end{array}$ & $\begin{array}{c}\text { Faktor Penyesuaian } \\
\text { Ukuran Kota }\left(\mathrm{F}_{\mathrm{CS}}\right)\end{array}$ \\
\hline Sangat Kecil & $<0,1$ & 0,82 \\
\hline Kecil & $0,1-0,5$ & 0,88 \\
\hline Sedang & $0,5-1,0$ & 0,94 \\
\hline Besar & $1,0-3,0$ & 1,00 \\
\hline Sangat Besar & $>3,0$ & 1,05 \\
\hline
\end{tabular}

Hambatan samping adalah dampak terhadap kinerja lalu lintas dari aktivitas samping segmen jalan, seperti pejalan kaki (bobot $=5,0$ ), kendaraan umum/ kendaraan lain berhenti (bobot $=1,0$ ), kendaraan masuk/ keluar sisi jalan (bobot $=0,7$ ) dan kendaraan lambat (bobot $=0,4$ ) (MKJI 1997).

Tabel 6. Klasifikasi Hambatan Samping

\begin{tabular}{|c|c|c|c|}
\hline $\begin{array}{c}\text { Frekuensi } \\
\text { Bobot } \\
\text { Kejadian } 200 \\
\text { m /jam (dua } \\
\text { arah) }\end{array}$ & $\begin{array}{l}\text { Kondisi } \\
\text { Khusus }\end{array}$ & $\begin{array}{c}\text { Kelas } \\
\text { Hambatan } \\
\text { Samping }\end{array}$ & Kode \\
\hline$<100$ & $\begin{array}{c}\text { Daerah } \\
\text { permukiman: } \\
\text { Jalan dengan } \\
\text { jalan samping }\end{array}$ & $\begin{array}{l}\text { Sangat } \\
\text { Rendah }\end{array}$ & VL \\
\hline $100-299$ & $\begin{array}{c}\text { Daerah } \\
\text { permukiman: } \\
\text { beberapa } \\
\text { kendaraan } \\
\text { umum, dsb } \\
\end{array}$ & Rendah & $\mathrm{L}$ \\
\hline $300-499$ & $\begin{array}{c}\text { Daerah } \\
\text { Industri, } \\
\text { beberapa took } \\
\text { disisi jalan }\end{array}$ & Sedang & M \\
\hline $500-899$ & $\begin{array}{c}\text { Daerah } \\
\text { komersial, } \\
\text { aktivitas jalan } \\
\text { tinggi } \\
\end{array}$ & Tinggi & $\mathrm{H}$ \\
\hline$>900$ & $\begin{array}{c}\text { Daerah } \\
\text { komersial, } \\
\text { dengan } \\
\text { aktivitas } \\
\text { pasar di jalan }\end{array}$ & Sangat Tinggi & HV \\
\hline
\end{tabular}

Tabel 7. Faktor Penyesuaian Tipe Lingkungan Jalan, Hambatan Samping, dan Kendaraan Tak Bermotor

\begin{tabular}{|c|c|c|c|c|c|c|c|}
\hline \multirow{2}{*}{$\begin{array}{c}\text { Kelas Tipe } \\
\text { Lingkungan } \\
\text { Jalan RE }\end{array}$} & $\begin{array}{c}\text { Kelas } \\
\text { Hambatan } \\
\text { Samping } \\
\text { SF }\end{array}$ & \multicolumn{7}{|c|}{ Faktor Kendaraan Tak Bermotor } \\
\cline { 3 - 9 } & Tinggi & 0,93 & 0,88 & 0,84 & 0,79 & 0,74 & 0,70 \\
\hline \multirow{3}{*}{ Komersial } & Sedang & 0,94 & 0,89 & 0,85 & 0,80 & 0,75 & 0,70 \\
\cline { 2 - 9 } & Rendah & 0,95 & 0,90 & 0,86 & 0,81 & 0,76 & 0,71 \\
\cline { 2 - 8 } Permukiman & Tinggi & 0,96 & 0,91 & 0,86 & 0,82 & 0,77 & 0,72 \\
\cline { 2 - 8 } & Sedang & 0,97 & 0,92 & 0,87 & 0,82 & 0,77 & 0,73 \\
\cline { 2 - 8 } & Rendah & 0,98 & 0,93 & 0,88 & 0,83 & 0,78 & 0,74 \\
\hline \multirow{2}{*}{$\begin{array}{c}\text { Akses } \\
\text { Terbatas }\end{array}$} & $\begin{array}{c}\text { Tinggi/se } \\
\text { dang/ren } \\
\text { dah }\end{array}$ & 1,00 & 0,95 & 0,90 & 0,90 & 0,80 & 0,75 \\
\hline
\end{tabular}

Faktor penyesuaian belok kiri $\left(\mathrm{F}_{\mathrm{LT}}\right)$ dihitung menggunakan persamaan (3), sebagai berikut:

$\mathrm{F}_{\mathrm{LT}}=0,84+1,61 \mathrm{P}_{\mathrm{LT}}$

Keterangan:

$\mathrm{F}_{\mathrm{LT}}=$ Faktor penyesuaian belok kiri

$\mathrm{P}_{\mathrm{LT}}=$ Rasio arus belok kiri

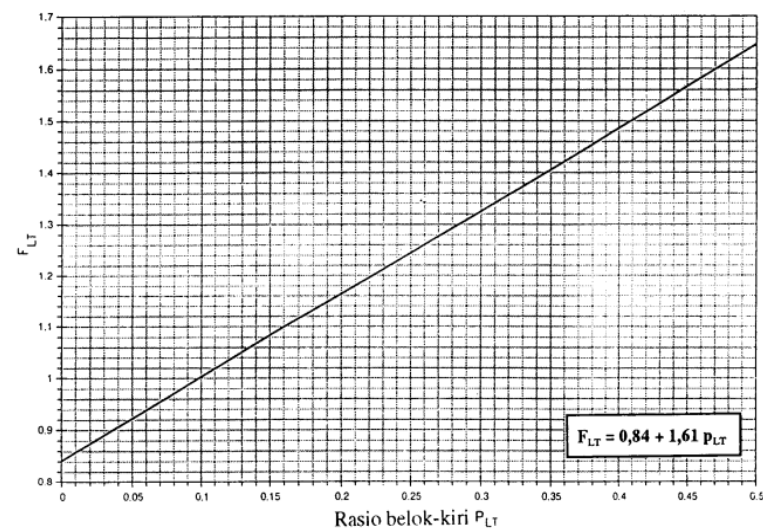

Gambar 1. Faktor Penyesuaian Belok Kiri $\left(\mathrm{F}_{\mathrm{LT}}\right)$

Faktor penyesuaian belok kanan $\left(\mathrm{F}_{\mathrm{RT}}\right)$ ditentukan berdasarkan jumlah lengan simpang, dimana jumlah lengan simpang yang ditetliti ada 4 lengan, maka dihitung menggunakan persamaan (4), sebagai berikut:

$\mathrm{F}_{\mathrm{RT}}=1,00$

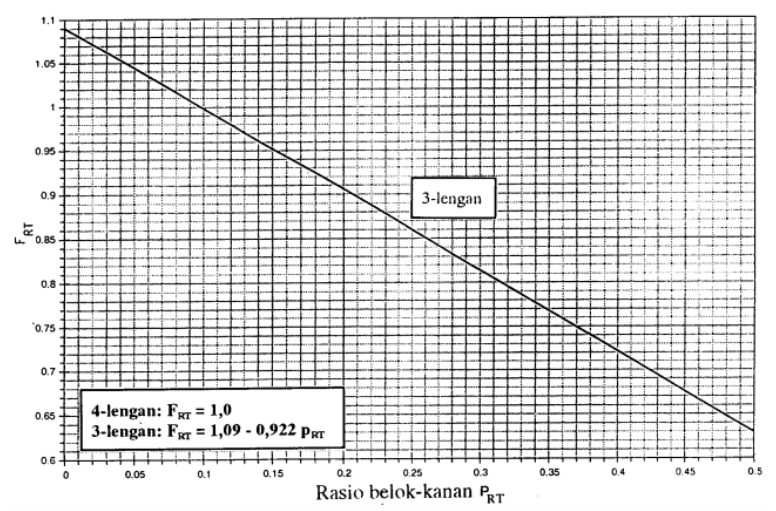

Gambar 2. Faktor Penyesuaian Belok Kanan $\left(\mathrm{F}_{\mathrm{RT}}\right)$

Faktor penyesuaian rasio jalan minor $\left(\mathrm{F}_{\mathrm{MI}}\right)$ dipengaruhi oleh tipe simpang, dimana tipe simpang 
yang digunakan adalah 422 maka dihitung menggunakan persamaan (5), sebagai berikut:

$\mathrm{F}_{\mathrm{MI}}=1,19 \times \mathrm{P}_{\mathrm{MI}}^{2}-1,19 \times \mathrm{P}_{\mathrm{MI}}+1,19$

(5)

Keterangan:

$\mathrm{F}_{\mathrm{MI}}=$ Faktor penyesuaian jalan minor

$\mathrm{P}_{\mathrm{MI}}=$ Rasio arus belok kanan

Nilai DS (Degree of Saturation) diperoleh dengan membandingkan arus lalu lintas total $\left(\mathrm{Q}_{\mathrm{TO}}\right)$ dengan Kapasitas (C) menggunakan persamaan (6), sebagai berikut:

$\mathrm{DS}=\mathrm{Q}_{\mathrm{Tот}} / \mathrm{C}$

Selanjutnya tundaan lalu lintas simpang $\left(D T_{I}\right)$ adalah tundaan lalu lintas rata-rata untuk semua kendaraan bermotor yang masuk simpang. Tundaan lalu lintas simpang $\left(\mathrm{DT}_{\mathrm{I}}\right)$ dihitung menggunakan persaman (7), tundaan lalu lintas jalan utama (DT $\mathrm{DA}_{\mathrm{MA}}$ ) dihitung menggunakan persamaan (8) dan tundaan lalu lintas jalan minor (DT $\mathrm{DI}_{\mathrm{MI}}$ ) dihitung menggunakan persamaan (9), sebagai berikut:

$$
\begin{gathered}
\mathrm{DT}_{\mathrm{I}}=\left(\frac{1,0504}{0,2742-0,2042 D S}\right)-(1-D S) \times 2 \\
\mathrm{DT}_{\mathrm{MA}}=\left(\frac{1,05034}{0,346-0,246 D S}\right)-(1-D S) \times 1,8 \\
\mathrm{DT}_{\mathrm{MI}}=\left(\mathrm{Q}_{\mathrm{TOT}} \times \mathrm{DT}_{\mathrm{I}}-\mathrm{Q}_{\mathrm{MA}} \times \mathrm{DT}_{\mathrm{MA}}\right) / \mathrm{Q}_{\mathrm{MI}}
\end{gathered}
$$

Keterangan:

$\mathrm{Q}_{\mathrm{MA}}=$ Arus lalu lintas total jalan mayor

$\mathrm{Q}_{\mathrm{MI}}=$ Arus lalu lintas total jalan minor

Variabel masukan dalam perhitungan tundaan geometrik simpang (DG) meliputi DS dan rasio belok total $\left(\mathrm{P}_{\mathrm{T}}\right)$. Maka, digunakan persamaan (10), sebagai berikut;

$D G=(1-D S) \times\left(\rho_{\mathrm{T}} \times 6+\left(1-\rho_{\mathrm{T}}\right) \times 3+\mathrm{DS} \times 4(\mathrm{det} / \mathrm{smp})(10)\right.$

Tundaan simpang (D) adalah total tundaan akibat volume lalu lintas dan geometrik jalan, dimana tundaan simpang tersebut dihitung menggunakan persamaan (11), sebagai berikut:

$\mathrm{D}=\mathrm{DG}+\mathrm{DT}_{\mathrm{I}}$

Rentang peluang antrian ditentukan dari hubungan empiris antara peluang antrian dan derajat kejenuhan, untuk lebih jelasnya dapat dilihat pada Gambar (1) atau persamaan (12) dan (13), sebagai berikut:

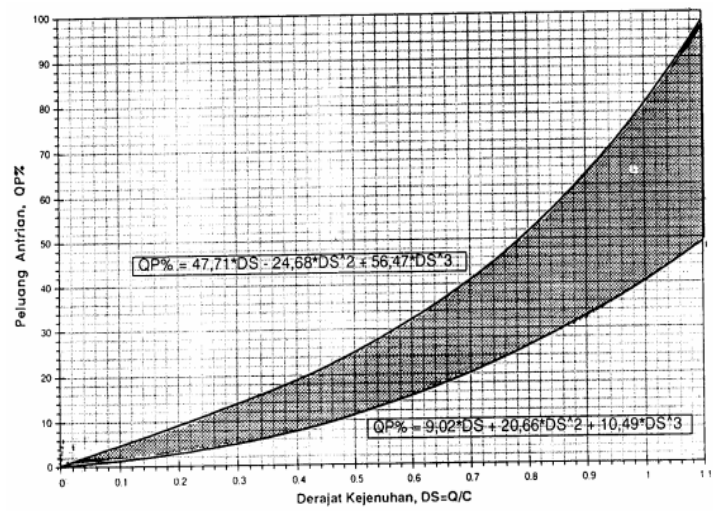

Gambar 3. Rentang Peluang Antrian (QP\%)
$\mathrm{QP} \%$ Batas atas $=47,71 \mathrm{DS}-24,68 \mathrm{DS}^{2}+56,47 \mathrm{DS}^{3}$ (12)

$\mathrm{QP} \%$ Batas bawah $=9,02 \mathrm{DS}-20,66 \mathrm{DS}^{2}+10,49 \mathrm{DS}^{3}$

Level of Service (LOS) atau tingkat pelayanan jalan merupakan indikator yang terdiri dari gabungan beberapa parameter baik secara kuantitatif maupun kumulatif dari suatu ruas jalan.

Menurut Peraturan Menteri Republik Indonesia No. PM 96 Tahun 2015 tingkat pelayanan jalan sebagai berikut:

Tabel 8. Tingkat Pelayanan Lalu Lintas

\begin{tabular}{|c|c|c|}
\hline $\begin{array}{c}\text { Tingkat } \\
\text { Pelayanan }\end{array}$ & $\begin{array}{c}\text { \% Derajat } \\
\text { Kecepatan } \\
\text { Arus Bebas }\end{array}$ & $\begin{array}{c}\text { Derajat } \\
\text { Kejenuhan } \\
\text { (DS) }\end{array}$ \\
\hline A & 90 & 0,35 \\
\hline B & 70 & 0,34 \\
\hline C & 50 & 0,77 \\
\hline D & 40 & 0,93 \\
\hline E & 33 & 1,00 \\
\hline F & 33 & 1,00 \\
\hline
\end{tabular}

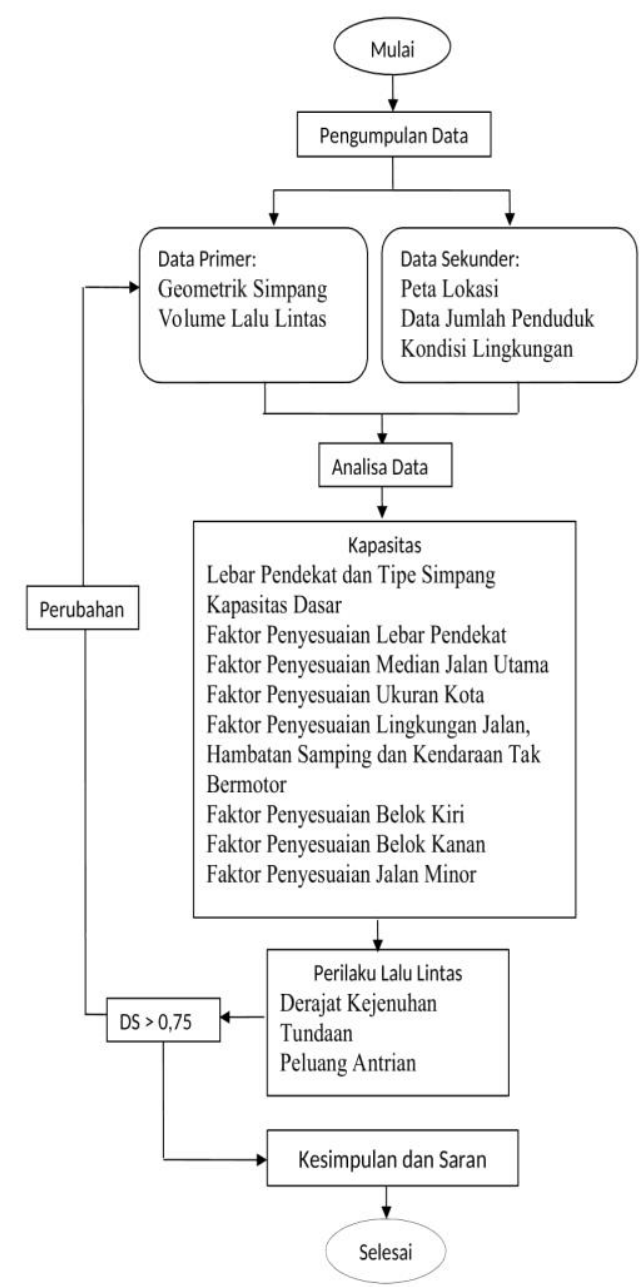

Gambar 4. Bagan Alir Penelitian 


\section{HASIL DAN DISKUSI}

\section{Analisa Simpang Tak Bersinyal}

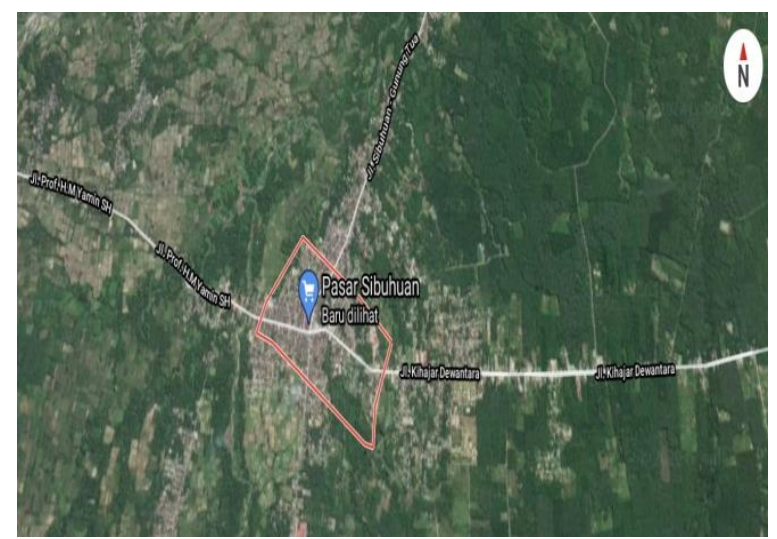

Gambar 5. Denah Lokasi

Hasil geometrik simpang didapat langsung dari pengamatan dan pengukuran dilapangan yaitu simpang empat pasar sibuhuan. Pengamatan pada saat survey menemukan bahwa persimpangan tak bersinyal Pasar Sibuhuan merupakan pertemuan dari Jl. Kihajar Dewantara - Jl. Prof. H. M Yamin SH sebagai jalan utama, dan Jl. Sibuhuan-Gunung Tua Jl. Surapati sebagai jalan minor. Simpang ini memiliki 4 lengan dan setiap lengan 2 jalur dan 2 lajur tanpa median. Lebar jalan utama 10,60 m (Lengan Timur) dan 10, $40 \mathrm{~m}$ (Lengan Barat), sedangkan pada jalan minor adalah 9,90 m (Lengan Utara) dan 9,20 m (Lengan Selatan).

\section{Kondisi Lingkungan}

Hasil kondisi lingkungan diperlukan untuk perhitungan kapasitas simpang sebagai berikut:

1. Tipe Lingkungan Jalan

Berdasarkan rancangan peraturan daerah Kabupaten Padang Lawas tahun 2011-2031 pada bagian ketiga rencana sistem jaringan prasarana, paragraph 1 rencana sistem jaringan dan transportasi, pasal 12 ayat (3) persimpangan tak bersinyal Pasar Sibuhuan menurut statusnya termasuk kedalam jalan kolektor primer yang menghubungkan antara ibu kota Kabupaten atau kota, dan menurut kelasnya termasuk kedalam kelas III B yang merupakan jalan kolektor yang dapat dilalui kendaraan bermotor termasuk muatan dengan ukuran lebar tidak melebihi 2.500 milimeter, ukuran panjang 12.000 milimeter dan muatan sumbu yang diizinkan 8 ton. Dalam penjelasan buku Manual Kapasitas Jalan Indonesia (MKJI) 1997 tentang tipe lingkungan jalan, bahwa lokasi penelitian ini termasuk kedalam wilayah komersial (COM). Untuk lebih jelasnya dapat dilihat pada Gambar 6.

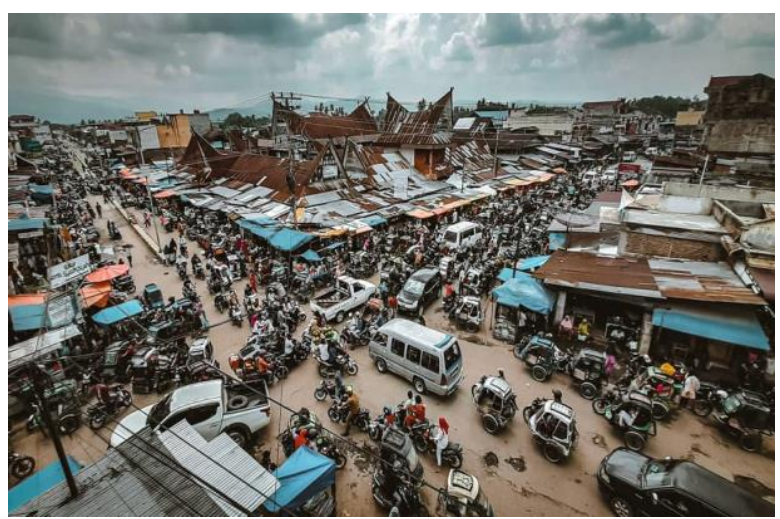

Gambar 6. Tata Guna Lahan Persimpangan Tak Bersinyal Pasar Sibuhuan

\section{Hambatan Samping}

Berdasarkan hasil pengamatan dilapangan, bobot kejadian nilai hambatan samping pada jam puncak maksimum sebesar 639,7. Dimana untuk interval pada bobot 500-899 diklasifikasikan dengan hambatan samping tinggi, maka dapat disimpulkan untuk kelas hambatan samping pada persimpangan tak bersinyal pasar Sibuhuan termasuk dalam kategori tinggi. Hal ini disebabkan banyaknya pejalan kaki, pengendara yang parkir disisi jalan, kendaraan keluar masuk, pada lengan simpang dan kendaraan lambat. Untuk lebih jelasnya dapat dilihat pada Gambar 7.

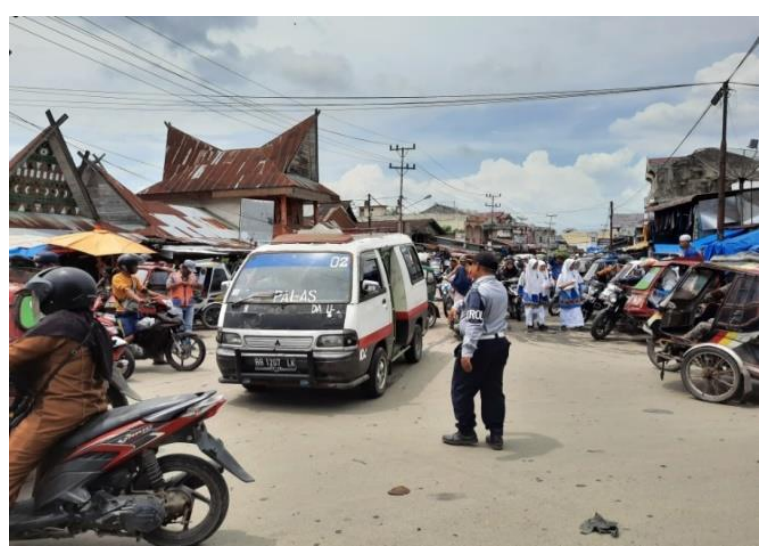

Gambar 7. Hambatan Samping Persimpangan Tak Bersinyal Pasar Sibuhuan

\section{Volume Arus Lalu Lintas}

Volume arus lalu lintas yang melewati persimpangan simpang tak bersinyal Pasar Sibuhuan di amati 2 (dua) hari pada hari kerja (Senin dan Selasa) dan 1 (satu) hari tak kerja (Sabtu) dengan 3 (tiga) sesi yaitu, jam 06.00-08.00 WIB, jam 12.00-14.00 WIB dan jam 16.00-18.00 WIB, dengan hasil volume lalu lintas masksimum terdapat pada hari Selasa di jam 12.00-14.00 WIB dengan nilai volume lalu lintas sebesar 2341 smp/jam. Untuk lebih jelasnya dapat dilihat pada Tabel 7, sebagai berikut: 
Tabel 9. Rekapitulasi Volume Lalu Arus Lintas

\begin{tabular}{|r|c|c|}
\hline Hari & Periode & $\begin{array}{c}\text { Volume Arus Lalu LIntas } \\
\text { (smp/jam) }\end{array}$ \\
\hline \multirow{3}{*}{ Senin } & $06.00-08.00$ & 2315 \\
\cline { 2 - 3 } & $12.00-14.00$ & 2341 \\
\cline { 2 - 3 } & $16.00-18.00$ & 2328 \\
\hline \multirow{3}{*}{ Selasa } & $06.00-08.00$ & 2298 \\
\cline { 2 - 3 } & $12.00-14.00$ & 2333 \\
\cline { 2 - 3 } & $16.00-18.00$ & 2311 \\
\hline \multirow{3}{*}{ Sabtu } & $06.00-08.00$ & 2278 \\
\cline { 2 - 3 } & $12.00-14.00$ & 2209 \\
\cline { 2 - 3 } & $16.00-18.00$ & 2220 \\
\hline
\end{tabular}

Dari data diatas dapat diketahui bahwa jam paling padat pada arus lalu lintas persimpangan tak bersinyal Pasar Sibuhuan terdapat pada hari Senin periode 12.00-14.00 WIB dengan jumlah 2341 smp/jam. Dikarenakan pada hari tersebut terdapat Pasar yang tingkat keramaiannya lebih tinggi dari hari biasanya, serta pada periode tersebut terdapat aktivitas pulang anak sekolah dan jam istirahat kantor.

\section{Kapasitas Simpang Tak Bersinyal}

Tabel 10. Hasil Analisa Kapasitas (C) Persimpangan Tak Bersinyal Pasar Sibuhuan Pada Jam Puncak Maksimum

\begin{tabular}{|c|c|c|c|c|c|c|c|c|c|}
\hline \multirow{3}{*}{ Kondisi } & \multirow{2}{*}{$\begin{array}{c}\text { Kapasitas } \\
\text { dasar Co } \\
(\text { smp/jam })\end{array}$} & $\begin{array}{c}\text { Lebar Pendekat } \\
\text { Rata-rata } \mathrm{F}_{\mathrm{W}}\end{array}$ & $\begin{array}{c}\text { Median Jalan } \\
\text { Utama } \mathrm{F}_{\mathrm{M}}\end{array}$ & $\begin{array}{c}\text { Ukuran } \\
\text { Kota } \mathrm{F}_{\mathrm{CS}}\end{array}$ & $\begin{array}{c}\text { Hambatan } \\
\text { Samping } \mathrm{F}_{\mathrm{RSU}}\end{array}$ & $\begin{array}{c}\text { Belok Kiri } \\
\mathrm{F}_{\mathrm{LT}}\end{array}$ & $\begin{array}{c}\text { Belok Kanan } \\
\mathrm{F}_{\mathrm{RT}}\end{array}$ & $\begin{array}{c}\text { Rasio minor/ } \\
\text { total } \mathrm{F}_{\mathrm{MI}}\end{array}$ & $\begin{array}{c}\text { Kapasitas C } \\
(\mathrm{smp} / \mathrm{jam})\end{array}$ \\
\hline Eksisting & 2900 & 1,04 & 1,00 & 0,88 & 0,83 & 1,38 & 1,00 & 0,89 & 2707,06 \\
\hline
\end{tabular}

Dari tabel 8 dapat dilihat hasil analisa kapasitas pada persimpangan tak bersinyal Pasar Sibuhuan pada jam puncak maksimum diperoleh nilainya sebesar 2707,06 smp/jam.
Hal ini disebabkan tingginya nilai hambatan samping sehingga diperoleh nilai kapasitas yang tinggi.

\section{Perilaku Lalu Lintas}

Tabel 11. Perilaku Lalu Lintas

\begin{tabular}{|c|c|c|c|c|c|c|c|c|c|c|}
\hline \multirow[t]{2}{*}{ Kondisi } & $\begin{array}{l}\text { Arus Lalu } \\
\text { Lintas } \\
\text { (smp/jam) }\end{array}$ & $\begin{array}{c}\text { Derajat } \\
\text { Kejenuhan }\end{array}$ & $\begin{array}{c}\text { Tundaan Lalu } \\
\text { Lintas Simpang } \\
\text { (det/smp) }\end{array}$ & $\begin{array}{l}\text { Tundaan Lalu } \\
\text { Lintas Jalan } \\
\text { Utama (det/smp) }\end{array}$ & $\begin{array}{c}\text { Tundaan Lalu } \\
\text { Lintas Jalan } \\
\text { Minor (det/smp) }\end{array}$ & $\begin{array}{c}\text { Tundaan } \\
\text { Geometrik } \\
\text { Simpang (det/smp) }\end{array}$ & $\begin{array}{l}\text { Tundaan } \\
\text { Simpang } \\
\text { (det/smp) }\end{array}$ & \multicolumn{2}{|c|}{ Peluang Antrian (\%) } & Sasaran \\
\hline & Q & DS & $\mathrm{DT}_{\mathrm{I}}$ & $\mathrm{DT}_{\mathrm{MA}}$ & $\mathrm{DT}_{\mathrm{MI}}$ & DG & D & Batas Bawah & Batas Atas & \\
\hline Eksisting & 2341 & 0,86 & 10,49 & 7,64 & 14,01 & 4,13 & 14,62 & 30,03 & 59,32 & DS $>0,75$ \\
\hline
\end{tabular}

Berdasarkan hasil analisa perilaku lalu lintas pada tabel 9, nilai derajat kejenuhan (DS) sebesar 0,86, tundaan (D) sebesar 14,62 dan peluang antrian $30,03 \%$ - 59,32\%. Dari hasil analisa tersebut diketahui bahwa kondisi operasional rendah. Hal ini ditunjukkan dengan nilai derajat kejenuhan $>0,75$ (MKJI 1997). Dengan nilai DS yang tinggi menyebabkan nilai tundaan dan peluang antrian yang semakin besar.

\section{KESIMPULAN}

Berdasarkan hasil penelitian yang dilakukan, maka dapat disimpulkan bahwa volume lalu lintas jam puncak tertinggi terjadi pada hari Senin, 16 Maret 2020 di jam 12.00-14.00 WIB dengan volume lalu lintas sebesar $2341 \mathrm{smp} / \mathrm{jam}$. Dengan hasi analisa yang diperoleh pada persimpangan tak bersinyal Pasar Sibuhuan dilakukan pada 2 (dua) hari sibuk yaitu Senin dan Selasa, dan hari tak sibuk di hari Sabtu, dengan 3 (tiga) sesi yaitu Pagi, Siang, dan Sore dengan nilai DS $>0,75$. Dimana nilai kapasitas (C) simpang sebesar 2707,06 smp/jam, derajat kejenuhan (DS) sebesar 0,86, tundaan simpang sebesar 14,62 det/smp, dan peluang antrian (QP) 30,03\%- 59,32\%.

\section{REFERENSI}

[1] P. Ilmiah, M. T. Putra, P. Studi, T. Sipil, F. Teknik, and U. M. Surakarta, "ANALISA KINERJA SIMPANG TAK BERSINYAL DAN BUNDARAN PURWOSARI (Jl. Slamet Riyadi Jl. Kh. Agus Salim Surakarta)," 2017.

[2] N. L. W. R. Kurniati, "Optimalisasi Kinerja Simpang Pasar Pagi Arenka Di Kota Pekanbaru Performance Optimation on the Intersection of Arenka Market in the City of Pekanbaru," Transp. Res., no. 5, pp. 133-146, 2016.

[3] N. Rorong, L. Elisabeth, and J. E. Waani, "Analisa Kinerja Simpang Tidak Bersinyal Di Ruas Jalan S.Parman Dan Di.Panjaitan," Fak. Tek. Jur. Sipil Univ. Sam Ratulangi Manad., vol. 3, no. 11, pp. 747-758, 2015.

[4] P. Sugiharti and W. Widodo, "Analisis Kinerja Simpang Tak Bersinyal ( Studi Kasus: Simpang 3 Tak Bersinyal Jl. Raya 
Seturan-Jl. Raya Babarsari-Jl. Kledokan, Depok, Sleman, Yogyakarta)," Konf. Nas. Tek. Sipil 7 (KoNTekS 7), vol. 7, no. KoNTekS 7, pp. 24-26, 2013.

[5] A. J. Wikrama, "Studi Simpang Tak Bersinyal (Studi Kasus: Jalan Raya Uluwatu - Jalan Raya Kampus Unud)," 2017.

[6] J. Barat, "Analsis Kinerja Simpang Tak Bersinyal Jalan Raya Dramaga-Bubulak," J. Tek. Sipil dan Lingkung., vol. 4, no. 1, pp. 6978, 2019.

[7] S. Anjarwati, "ANALISIS KINERJA SIMPANG BERSINYAL DUKUHWALUH PURWOKERTO (Analyze of Intersection Street Performance in Dukuhwaluh Purwokerto )," Techno, ISSN 1410 - 8607, vol. 15, no. 1, pp. 14-20, 2014.

[8] Juniardi, "Analisis Arus Lalu Lintas Di Simpang Tak Bersinyal," Tesis Progr. Pascasarj. Univ. Diponegoro Semarang, 2006.

[9] A. Alhadar, "Analisis Kinerja Jalan dalam Upaya Mengatasi Kemacetan Lalu Lintas pada Ruas Simpang Bersinyal di Kota Palu," J. SMARTek, Nop. 2011, vol. 9, no. 4, pp. 327336, 2011.

[10] Arbima dkk, "Analisis Kinerja Simpang Tak Bersinyal Empat Lengan (Studi Kasus Simpang Tak Bersinyal Empat Lengan Jalan Wates Km.5, Gamping, Sleman, Yogyakarta)," Uii, p. Yogyakarta, 2015.

[11] "HIGHWAY CAPACITY MANUAL PROJECT ( HCM )," vol. 7802112, no. 264, 1997.

[12] J. Portal, "MANAJEMEN LALU LINTAS PADA PERSIMPANGAN JALAN B.ACEH-MEDAN CUNDA-LHOKSEUMAWE Rosalina Staf Pengajar Jurusan Teknik Sipil Politeknik Negeri Lhokseumawe," vol. 2, no. 2, pp. 111, 2010.

[13] N. Tahun and U.- Analisa, "ANALISA KAPASITAS RUAS JALAN CENDANA DENGAN Fakultas Teknik Jurusan Sipil Universitas 17," pp. 1-8, 2007.

[14] K. Samarinda and M. A. Ramadhan, "( Studi Kasus Pada Simpang Jl . Untung Suropati - Jl . Ir . Sutami - Jl . Selamet,” pp. 1-14, 1945.

[15] M. Daryl and M. Pratama, "Analisis Kinerja Simpang Tak Bersinyal Jalan A . H . Nasution dan Jalan Cikadut, Kota Bandung," vol. 5, no. 2, 2019.

\section{NOMENKLATUR}

$\mathrm{C}=$ Kapasitas

$\mathrm{C}_{\mathrm{o}} \quad=$ Kapasitas dasar

$\mathrm{D} \quad=$ Tundaan simpang

DG = Tundaan geometric simpang

DS = Derajat Kejenuhan

$\mathrm{DT}_{\mathrm{I}}=$ Tundaan lalu lintas simpang

$\mathrm{DT}_{\mathrm{MA}}=$ Tundaan lalu lintas jalan utama

$\mathrm{DT}_{\mathrm{MI}}=$ Tundaan lalu lintas jalan minor

$\mathrm{F}_{\mathrm{CS}}=$ Faktor penyesuaian ukuran kota

$\mathrm{F}_{\mathrm{LT}}=$ Faktor penyesuaian belok kiri

$\mathrm{F}_{\mathrm{M}}=$ Faktor penyesuaian median jalan utama

$\mathrm{F}_{\mathrm{MI}}=$ Faktor penyesuaian arus jalan minor
$\mathrm{F}_{\mathrm{RSU}}=$ Faktor penyesuaian tipe lingkungan jalan, hambatan samping dan kendaraan tak bermotor

$\mathrm{F}_{\mathrm{RT}}=$ Faktor penyesuaian belok kanan

$\mathrm{F}_{\mathrm{W}}=$ Faktor penyesuaian lebar pendekat hambatan samping dan kendaraan tak

LT = Belok kiri

$\mathrm{P}_{\mathrm{LT}}=$ Arus belok kanan

$\mathrm{P}_{\mathrm{LT}}=$ Arus belok kiri

$\mathrm{P}_{\mathrm{MI}}=$ Rasio arus belok kanan

$\mathrm{P}_{\mathrm{UM}}=$ Rasio antara arus kendaraan tak bermotor

$\mathrm{Q} \quad=$ Volume lalu lintas

$\mathrm{Q}_{\mathrm{MI}}=$ Jumlah arus total pada jalan mayor

$\mathrm{Q}_{\mathrm{MI}}=$ Jumlah arus total pada jalan minor

$\mathrm{QP}=$ Peluang antrian

RT = Belok kanan

$\mathrm{ST}=$ Lurus

$\mathrm{W}_{1}=$ Lebar pendekat rata-rata

WA = Lebar pendekat jalan minor (utara)

$\mathrm{W}_{\mathrm{AC}}=$ Lebar pendekat rata-rata jalan minor

$\mathrm{WB}$ = Lebar pendekat jalan mayor (timur)

$\mathrm{W}_{\mathrm{BD}}=$ Lebar pendekat rata-rata jalan mayor

$\mathrm{WC}=$ Lebar pendekat jalan minor (selatan)

$\mathrm{WD}=$ Lebar pendekat jalan minor (barat)

$\rho_{\mathrm{T}} \quad=$ Rasio belok 
This page is intentionally blank 